\title{
Variation of the Subject Divisional Plan at Oregon
}

Mr. Morrison is head social science librarian, University of Oregon Library.

$\mathrm{T}^{\mathrm{n}}$ HE FUNDAMENTAL purpose underlying the recent reorganization of the University of Oregon Library is to facilitate and encourage research processes appropriate to each level of the University program. The idea is to provide special services in subject fields and yet take into account the essential unity of knowledge; to remove all possible barriers between the library's resources and its readers but at the same time provide adequate control for the collections.

This reorganization has been in the planning stage since 1946 and was put into effect coincident with the occupation of an extensive addition to the library's physical plant in October 1950. ${ }^{1}$ The new plan involves a subject-divisional organization but, as will be shown, varies considerably from the plan generally implied in the words "divisional library."

In the description of the plan, note may be taken of four features designed to preserve unity in the collections and services: (I) that architectural considerations were important, since the main library building was designed specifically to house a conventional departmental organization, while the new annex is a modular structure providing the flexibility required for subjectoriented services; (2) that since the faculty members of the University were accustomed to receiving a high level of service under the old organization, it seemed

1 Morrison, P. D. "Organization Not Frozen in Brick and Stone," Library Journal, 76:194-6, Feb. I, I95 I. unwise to eliminate any efficiently-functioning, well-received services; (3) that it did not seem desirable to fragment one of the best examples of a medium-sized library collection which is both physica'ly and administratively centralized under one roof; and (4) that neither ideas nor books will all fit into logically tight compartments. General services are needed to cut across subject lines.

For these reasons three unified services were maintained-and one added. The book stock was retained in one classified sequence instead of being broken up into the core collections featured in most divisionalplan libraries.

The first of the three centralized services retained was that of general reference. The purpose of this service is to give reference assistance in "breadth" as opposed to "depth." This means that the General Reference Division handles requests for specific facts which can be obtained from such general compilations as encyclopedias, yearbooks and periodical indexes which tend to ignore subject boundaries and treat the world of knowledge as a whole. Such questions usually come from undergraduates.

The second "breadth" service is the maintenance of a single reserve book room-on an open shelf basis-to house and service books for assigned undergraduate reading. No segregated reserves are maintained in the subject divisions. Like General Reference, General Reserve is maintained to support the unified, general-education features of the University curriculum. 
A third unified service is that of a centralized circulation department. The efficiency of having all circulation controlled from one point has not only saved money but also freed professional subject-specialist librarians from the duty of supervising circulation routines and enabled them to concentrate on the bibliographic, selection and instructional services discussed below. ${ }^{2}$ 'This efficiency of control was made possible by the fact that the collection is shelved in a single sequence and hence no subsidiary circulation points are needed in the subject areas. (One exception is the case of periodicals which circulate only on special permission of divisional librarians and are recorded by them.) The self-service principle has also promoted economy in the centralized control of circulation. The only paging done is of a deferred-search basis. It should be noted, however, that some of the personnel saved by centralized circulation control is used in the increased shelf-reading activity required in open-stack operation.

The fourth centralized service is a centralized government and international documents service. This service, now in the process of being established, is administratively a part of the General Reference Division. Current plans call for the documents unit to be a clearing house for information concerning the location and contents of government publications. It will contain a relatively small collection of not-fully-cataloged documents to include the "Serial Set" of U.S. government reports and current numbers of established serials - the latter to be placed in the main stacks when bound. Also in the documents area will be a small collection of mimeographed or otherwise processed documents which do not require full cataloging or permanent binding. The decision as to how much and

${ }^{2}$ Apparently the University of Nebraska has come to the same conclusion by trial and error processes. $C f$. Patricia Marvin. "Circulation in the Divisional $\mathrm{Li}$ brary: The New Plan of Service," College and Re. search Libraries, I 2:24I-4, July I, I 95 I. what type of governmental publications should go into a documents collection is a difficult one to make. On the one hand, a large segregated documents collection would tend to violate the principle that, in a subject-orientated organization, material should be arranged according to subject rather than by form or publisher. On the other hand, much document material is difficult to locate and control when placed in the regular stack sequence. Two considerations have prompted the decision to establish a documents center: (I) economy-printed United States and United Nations catalogs will serve in lieu of expensive locally-prepared card catalog entries-and (2) the desire on the part of the faculty that an administrative unit be primarily charged with the acquisition, arrangement and servicing of this complex body of material.

A final feature emphasizing unity is the maintenance of one sequence throughout the collection rather than the establishment of segregated groups in the subject divisions. Since the library is classified according to the Dewey system, certain rearrangements of large blocks of material were effected so that appropriate classes would group themselves into three segments-Science, Social Science, and Humanities. Thus, for example, the Dewey Ioo's as a unit were shelved in the Humanities area except for 150 (Psychology) which is in Social Science. Again, Business (650) was taken out of Science and placed in Social Science. However, within these large blocks the books remain in classified order and a directory tells the reader where each group of Dewey numbers is shelved. This scheme has made it possible to have divisional collections in three definite areas without relocating individual volumes as is the case where a selected core collection is pulled from the main stack sequence and placed in divisional reading rooms. The public catalog also is not cluttered with 
"half cards" or other locating devices to be constantly pulled and refiled.

The saving in administrative and clerical time under this arrangement is considerable. Students are not dismayed by having access to the entire mass of books on a given subject rather than being spoon-fed on a segregated collection in each subject division. For the advanced research worker, these are also advantages in a unified collection. The only segregated collections other than reference books and government documents are those in the Special Collections Division which maintains a collection of Oregon materials, manuscripts, rare books and other items not suitable for the general collection.

\section{Specialization and Depth}

What are the elements in the program contrived to give additional specialization and depth to these traditional services? In the first place it should be noted that the specialized units of service were not conceived as mere auxiliary components tacked on to existing library departments. Administratively the subject divisions-Science, Social Science, and Humanities-and the Special Collections Division (primarily concerned with Northwest Americana) are autonomous units reporting directly to the University Librarian. Although in some peripheral aspects precise definitions of function have not as yet crystallized, the plan calls for each special service to be responsible for a definite part of the collection and for developing a definite and distinctive part of the library's mission. Each division, for example, is charged with responsibility for maintaining liaison with the teaching faculty in its subject area.

The divisions provide service desks from which is given not only specialized reference service in the traditional meaning of the term but also what one might call "guidance in the research process." Although subject specialists help students and faculty with searches for specific items of information, an equally important function is the instruction-formal and informal-of advanced students in how to explore efficiently the literature of a subject and develop a research topic through the use of library resources. Such instruction is sometimes best given on a spur-of-the-minute basis and for this reason, divisional librarians are encouraged to circulate among the readers in the library rather than officiating behind a desk. Students starting a thesis are encouraged to register their topic with the appropriate divisional librarian and to request a consultation concerning the bibliography of the subject. Such consultations are conducted in a peripatetic fashion: the librarian takes the student (or sometimes a small group of students) directly to the collection of bibliographies and other documentation sources and then to the stack shelves where pertinent parts of the collection are located. Meanwhile he explains the functions of the various catalogs, reference tools and classification symbols demonstrating on the spot how to use efficiently the various parts of a bibliography, a cumulated index, or a monograph. In working with organized class groups-and this is also an integral part of the program -divisional librarians encourage faculty members to bring their classes or seminars to the library where meeting rooms are provided and where instruction can be given on the ground and where research methods can be demonstrated by practical example.

Another important divisional function is in the field of acquisitions both on the policy level and in nominating specific titles for purchase. In this activity the subject-specialist librarians work closely with the faculty. Each Division maintains a system for bringing appropriate titles to the 
attention of faculty members for possible purchase through the departmental allocation of book funds. Since a university library must have key works in most subject fields even though no academic department is doing intensive work in the area at the moment, divisional librarians select key works in fields peripheral to the subjects of concentrated interest. These are then purchased from the general library allocation.

Obviously these services call for librarians with special subject background as well as technical library training. Each subject division has two professional librarians with such training. Most of these librarians have advanced degrees in one or more of the disciplines served by the Division. Each Division has charge of the periodical collection in the area and is responsible for certain other routines connected with maintaining vertical files, compiling bibliographies, suggesting titles to the faculty for possible purchase, and providing special services such as a Curriculum Materials Laboratory (Social Science) or a Map Room (Science). Therefore, each Division is provided with a clerical assistant (with state civil service status) to prepare periodicals for binding, type bibliographies and reports, and provide such routine types of public service as direction-giving and locating specific titles while divisional librarians are employed in guidance and reference work.

Chronologically the first of these specialized services to be established was the Department-now Division-of Special Collections organized in 1948. In addition to consolidating the rare-book, manuscript and archival functions of the University; this Division has done much to promote and encourage research in Pacific Northwest History. In many ways the research, instructional and liaison work of the Special Collections Division served as a prototype for the more recently established subject divisions. Techniques and concepts found useful in aiding and promoting research in the field of Northwest Americana have been found applicable also to broader subject areas.

In October 1950, when the new annex to the building was occupied the plan went into full operation. Virtually every book in the collection was moved in order to achieve the configuration described above. The entire stack area (including all of the Annex) was opened to the public and the subject division services opened for business. Fewer shakedown troubles were experienced than had been anticipated: The open-shelf, self-service features were considered a great improvement by the vast majority of students as was the presence of trained service personnel throughout the building. A vigorous formal and informal education program soon accustomed students to the complexities of the building and to the subject-orientation of the periodical collection. A recent survey has revealed majority satisfaction with the essential feature of the new plan.

The Science Division was probably the first to hit its stride. A depression-born scheme to divide the fields of knowledge among the various institutions in the Oregon State System of Higher Education was modified shortly after World War II permitting the restitution to the University of a vigorous undergraduate and graduate program in the pure sciences. Thus, a partial vacuum had developed in the Library's collections and services during the period that science was deemphasized. Although much work had been done toward restoring the science collections prior to the establishment of the Science Division, the need for specialized library personnel in the sciences was acute. Science was thus a fertile field for promotional activity: The science departments of the University, often preoccupied 
with laboratory work and often with personnel accustomed to departmental library systems at other institutions, stood in need of a service which would point up the advantages of a centralized library to the scientist and which would coordinate the collections and services of the library with the needs of laboratory-orientated specialists.

As anticipated, the field of the social sciences is proving crucial to the success of the plan-and the one presenting the most difficulties. Among the problems faced by the division serving the numerous social science departments (including Education) are those arising from the fact that the collections under its jurisdiction are so much larger than those in the other two subject areas. The social science sequences extend over three different stack decks of the old building and two levels of the new annex. However, the present budget situation permits only enough personnel to staff one service point professionally. Thus, to give on-the-spot service, social science librarians have a large physical area to cover and a vast range of material to interpret. Also, it is more difficult to make a sharp distinction between functions appropriate to a specialized social science unit and those of a "general" nature. This arises in part from what bibliographic scholars have been recently referring to as "the poor state of documentation in the social sciences." Thus, while the specialist in the physical sciences relies on his special abstracting and indexing services, the social scientist must often secure what help he can from general indexes and catalogs. In practical terms this means that under the new plan especially close cooperation between the "general" and "special" services must be maintained. Some duplication of key reference works has been necessary since "depth" research in the fields of political science or sociology, for example, require exploitation of index and reference sources which were designed primarily for "broad" coverage of unspecialized knowledge. In spite of-or perhaps because of-these difficulties we feel that there is a great potential in the idea of presenting specialized services in the social sciences rather than in combining them administratively with the general services as is done in many divisional libraries. The very inadequacy of the instruments of bibliographic control in the social sciences points up the need for libraries to furnish services designed to fully exploit those which do exist-and perhaps contribute to the development of better techniques of documentation in these disciplines.

Although somewhat similar problems may confront the Humanities Division, the problem is less acute in this area and progress has been made in establishing a well-defined service to specialists in such fields as Literature, Philosophy, Religion, Languages, Speech and Music. Since there is relatively less preoccupation with recency of information here than in the other two fields, this Division has been able to achieve stability more rapidly than the other two. Because the bibliographic needs of, say, Freshman English students differ so markedly from those of faculty research workers in the field, the provision of separate service-indepth has been much appreciated by the latter. Due to the fact that a laboratory collection in Architecture and Allied Arts is located in another building, the chief coordinating activity in the humanities has been required in this subject field. Here again the advantages of centralization of collections is being stressed with specialized staff and flexible service preferred over fragmentation of the collections and services into departmental libraries.

Essential to all of the other features of the Oregon plan is the idea that very nearly 
all barriers between readers and books can and should be removed. The stacks have been thrown open to all students and complete freedom of movement within the building is permitted. Books and magazines may be used anywhere in the stack areas (where the divisional services are also located) without charging or other formalities. In leaving the stack-and-study area, students pass a charging and inspection point. Loss of books has not been excessive so far and a survey has shown that all ctasses of students and faculty prefer the open stack over the traditional closed-stack system. Studious undergraduates especially appreciate stack access and the fact that reading tables and special reference services are located right among the books. Since all books and services are open to all, each student may pursue his studies to whatever depth he cares without artificial barriers based on academic rank. In this connection it should be noted that while the special subject services are oriented toward upper division, graduate and faculty research, they are open to-and frequently patronized by - lower division students who are encouraged not to restrict their quest for knowledge to the assigned reading in the reserve room.

Obviously the system outlined above offers a wide range of services to a student body of about 4500 . Yet the staff has not been greatly expanded in order to make it possible. Although the library nearly doubled in physical area, the only additions to the staff were the three subject specialists to head the divisions. Recently sometemporary, we hope-reductions in staff were made necessary by the decrease in enrolment and consequently in budget typical of higher institutions throughout the country. While ideally certain additions to the staff are desirable-notably an education librarian in the Social Science Division- the plan is a going concern with about the same staff as that required for a traditional library of the same size (approaching a half million volumes). Indicative of the effect of the reorganization were the congratulations offered by a faculty member on the large increase in staff the library had secured-when actually only a very small number had been added! The secret of the plan's ability to give rather sophisticated services on an ordinary budget seems to lie in the economies made possible by centralized circulation control and the decision to establish no segregated collections or catalogs. Energies which in other subject divisional libraries are spent in charging books and maintaining a selected "core" of five to ten thousand books in each divisional room are available under this plan for building a good collection and facilitating its use as a whole.

\section{Summary}

The University of Oregon version of the divisional plan is one which emphasizes two concepts: (I) That there is a dualistic need for both unity and variety in the world of learning and hence in library organization; (2) Energy is better spent in guiding students in the techniques of selecting material from a large body of recorded knowledge than in pre-selecting and segregating that which is theoretically "best" for him. 'The first concept calls for some services which cut across subject lines, for others which are subject-orientated and for opening the whole range of library resources to all students. The second concept has been met by maintaining collections in one sequence and by providing a maximum amount of guidance to students. Teaching the technique of selecting from the mass of material that which is most pertinent to the student's individual needs we call "guidance in the research process." 